ment is likely to lead to a long period of uncertainty about individual waterways, in which their condition and prospects would deteriorate, and ultimately to a more expensive and less efficient structure.

The need for early decision is reiterated throughout the report and is one factor responsible for the issue of an interim statement. Particularly in respect of some special cases, such as the Konnet and Avon Canal, the Leeds and Liverpool Canal and the main line of the Grand Union Canal, and some of those used for pleasure craft, the Board stresses the need to provide some reasonable assurance of continuity. The development and use of waterways have for generations been hindered by uncertainty about their future, and this prolonged uncertainty has exacerbated the very difficulties which caused it in the first place. The Waterways Board fully endorses the observations of the Bowes Committee on this point, and this applies to almost every ficld of the future activity of the waterways.

The Board argues very cogently that this policy of multi-user is the most rational and efficient policy, and it points out that the undortaking for which it has assumed responsibility cannot, as a whole, any longer be regarded solely as a national transport system. As such, some of it is manifestly out of date, though it might well be asked whether the practicability has boen sufficiently carefully considered of developing even some sections of the waterways as an alternative means of relieving the congested road system of some of the heavy traffic responsible for delays and damage, or to fill the gaps left by some of the closures of railway lines that have already been made or are in prospect. That, of course, properly lies outside the special responsibility of the Board, but once again it indicates the real danger of departmentalism which the handling so far of the Robbins Report and the Buchanan Report has demonstrated. Apart from that, however, the interim report on the future of the waterways shows clearly the impracticability of neatly and separately arre nging waterways as usable and unusable for transport, or evon separately labelling individual waters for single particular purposes.

All this is admirably shown on the excellent sories of charts with which the report is illustrated. Although, as has already been omphasized, the Board is careful to insist that its present views are subject to modification, the imaginative and constructive approaches it displays in its considerations of commercial transport and related activities, of water supply and channelling, and of the use of the waterways by pleasure craft, for eruising, angling and other purposes are some of the most encouraging and helpful features of the report. There is, for example, the comment that a reasonable transport diversity is a useful support to a healthy economy. Again, the Board notes that many waterways could without major expansion cater for more traffic than they do at the moment- the Lea, going through the industrial East End and the City to the London docks, is one example. It is clear that, given the reasonable support on which it should be able to count, the Board will be prepared to consider in due course with real vision the possibilities of major expansion or improvement or even the building of new waterways.

What does emerge from this interim report is that Britain now has a Waterways Board with a positive policy and one which is imaginatively alive to the many possibilities which such a policy holds for various aspects of public welfare, including the intelligent conservation and use of water resources. Although the revenue for angling is minute compared with the cost of maintaining waterways, that does not mean that angling will be disregarded by the Board, and it recognizes the complexity of the statutory position and is prepared to reconsider this in due course. Meanwhile, in a situation in which the annual rate of loss has been reduced from $£ 1 \cdot 3$ million to less than $£ 1$ million and could be reduced by a further $£ 0.75$ million if all went well, the Board is concentrating on the general concept of the multi-user system as the best opportunity of attracting new revenue. It is indeed also required by the Transport Act of 1962 to pay interest on a commencing debt, estimated at $£ 19 \cdot 2$ million, retention of which is scarcely a stimulus to sound financial management. Nevertheless, while the Board is not yet ready to make firm proposals regarding the future treatmont of this debt, it hopes to do so later. How the engineering survey and the systematic financial and costing investigations to be put in train will affect the tentative views expressed in this report has yet to be seen. It can at least be added, on the evidence of this report, that if the British Waterways Board does not, within the next few years, provide Britain with a waterways system which measures up to the opportunities displayed in this report with insight as well as realism, the responsibility is likely to be that of the Government, and particularly the Minister of Transport, for failing to support it. After this report, the Minister of Transport can have no excuse if he fails to deal urgently and constructively with the problems of administration involved at the central as well as at the regional level when problems have to be handled from the point of view of numerous functions and services, far transcending local, and sometimes regional, needs and interests.

\title{
DISEASES OF THE HOP
}

$\mathrm{C}$ OMMUNICATION between biologists in different 1 countries, working in different physical and intellectual environments, and publishing their results in different languages, is perhaps nowhere more difficult than in the field of plant virus diseases; the basis for identification of the causal agent still depends on the description of variable and often transient symptoms in one or more species or varieties of host plants, even though these diagnostic techniques are boing increasingly supplemented by data from the electron-microscope and the ultracentrifuge, and from serological investigations. Much can be gained by assembling an international group of specialists for a working conference to see and handle diseased material and to discuss common problems. This can be especially valuable if the proceedings of the conforence are not published in detail and the participants can therefore feel free to speculate. The conference on hop diseases, sponsored by the East Malling Research
Station with the Hop Research Department of Wye College, and held during June 29-July 2 at East Malling and Wye, was organized on this basis. The incentive for arranging the conference came initially from virus workers; but the programme also included discussions on the major fungal diseases of the hop.

The first day of the conference, under the chairmanship of D. Rudd Jones (Agricultural Research Council, U K.), was devoted entirely to virus diseases. Only one virus, hop mosaic, appears to be recognized in all the major hop-growing areas of the world, though it is not clear how much variation there is between strains of the virus. Papers on this disease dealt with its effect on the yield and quality of carly and late cluster hop varieties (C. B. Skotland, U.S.A.) and with changes induced by the virus in the mineral content of the leaves ( $R$. Marocke, France).

Kräuselkrankheit (crinkle) is a disease of economic importance in Germany and eastern Europe, but it is 
not recognized elsewhero. Its symptomatology and control in Czechoslovakia were discussed by J. Kriz (Czechoslovakia); and P. Chrometzka (Germany) showed how various climatic and nutritional conditions could lead to masking of the symptoms. A striking feature of the disease is the effectiveness with which symptoms can be eliminated by treating affected plants with zine salts or zinc-containing fungicides; this, together with the somewhat equivocal results of attempts to transmit the disease by grafting, suggests the possibility that zinc deficiency is directly involved.

Kräuselkrankheit symptoms have a number of features in common with those of nettlehead. A paper on the ætiology of this disease by J. T. Legg (U.K.) was presented by K. R. Bock (U.K.), the author boing at present in Ghana. This paper also dealt with hop line pattern virus, which can be latent in many varieties but which, when present, either facilitates infection with nettlehead virus or contributes to the development of the nettlehead syndrome. Nettlehead is not recognized in continental Europe, but is probably present in the United States.

Kräuselkrankheit is probably not synonymous with nettlehead; some evidence for this was mentioned in the text of a paper by H. E. Schmidt (D.D.R.). Unfortunately, no member of this author's laboratory, the Institut für Phytopathologie at Aschersleben, was able to attend the conference, and it was not possible to discuss in detail what appeared to be an important contribution to diagnostic procedures for hop viruses. For example, a number of herbaceous indicator plants have been used at Aschers. leben to differentiate strains of 'hop ring-and-bandingmosaic virus'. It was not possible to determine whether this virus is related to the hop line pattern virus described by Legg; the latter virus has not been recognized in Germany, Czechoslovakia or Yugoslavia, but is believed to be present in the United States.

Herbaceous indicators have also been used by D. H. Hall (U.S.A.) during investigations of a yellow leaf blotch virus of hops in California, a disease that seems to resemble one previously reported from New Zealand, but is apparently not recognized elsewhere.

Infectious sterility is recognized only in eastern continental Europe. It was discussed by J. Kriz, who indicated that control was likely to be achieved in the near future by the propagation of selected virus-free clones. This preventive approach to the control of virus diseases in general was also stressed in contributions to the discussion by delegates from western continental Europe, Britain and the United States, whereas in southern Germany the curative approach by treatments aimed at ameliorating the effects of the disease on the host plant is predominant.

Split leaf blotch, a disease well known in Britain, is possibly present in Europe and almost certainly present in the United States.

In the second sossion, under the chairmanship of W. G. Koyworth (U.K.), discussions on hop Verticillium wilt diseases were opened by G. W. F. Sewell (U.K.), P. W. Talboys (U.K.) and T. Christie (New Zealand).

The taxonomic position taken by most British workers is that the 'Dauermycelien' and 'microsclerotial' forms of Verticillium are referable to the two species $V$. alboatrum and $V$. dahliae, respectively. Though a majority of American pathologists have regarded theso as different forms of $V$. albo-atrum, an increasing number of them are accepting the division into two species as a matter of convenience if not always of conviction.

The major wilt pathogen of hops in Britain and Germany is $V$. albo-atrum, and limited outbreaks caused by this species have also occurred in New Zealand. In the United States relatively minor outbreaks in the past have been caused by $V$. dahliae; but C. E. Horner reported that a new occurrence of the disease in 1964 was caused by $V$. albo-atrum. In other countries hop wilt is of no economic significance and in most areas has not been reported.
The virulent strain of the-pathogen causing progressive wilt in Britain does not seem to occur elsewhere, though tests carried out in Germany and New Zealand to discover whether the strains present there correspond with those causing progressive and fluctuating wilt in Britain are difficult to assess because the techniques and environmental conditions of the trials were different from those in Britain. The marked response of Verticillium wilts to environmental conditions is an important factor to be considered in investigations both of resistance in the host and of virulence in the parasite. Thus, the initial development of the wilt problem in Germany, and the variable incidence of acute disease from year to year in moderately resistant varieties on certain sites in Britain, were both ascribed, at least in part, to low temperatures during the summer. The increasing prevalence of $V$. dahliae as a wilt pathogen in warmer climates is another aspect of the same problem.

Present investigations of the host-parasite relationship in England continue to lay stress on the importance of the extra-vascular root tissues in determining the severity of the disease.

Research on the status of $V$. albo-atrum in the soil indicates that infection of roots of dicotyledonous plants provides an important means of maintaining soil populations of the pathogen, whereas under a pure grass sward this organism is rapidly eliminated. V. dahliae, however, is apparently not amenable to this method of control.

Discussions on downy mildew (Pseudoperonospora humuli) fully occupied the third day under the chairmanship of J. E. Crosse (U.K.). The meeting was held at Wye College, and papers were presented by F. Zattler (Germany), J. M. Ogawa (U.S.A.), J. R. Coley-Smith (U.K.), C. E. Horner (U.S.A.), Y. Mori (Japan) and L. Vent on behalf of Z. Petrlik (Czechoslovakia).

Most of the discussion during this session was concerned with over-wintering of hop downy mildew and with the value of streptomycin in early-season control of the disease. In Great Britain, the United States and Japan there is now a great deal of evidence to show that downy mildew over-winters mainly as mycelium in infected hop rootstocks. Oospores of the fungus are very rare in the United States, and although of common occurrence in Britain have never been observed to germinate. On the continent of Europe it is still widely believed that spring infections arise from oospores, and there is certainly evidence that infection of hop rootstocks is less common there than in Britain or the United States.

There was disagreement about the value of streptomycin for early-season control of hop downy mildew. Good control has been achieved in certain areas of the United States but not in others. In Great Britain the antibiotic appears to give slightly better results than conventional protectant fungicides. Mixed results have been obtained in Japan, but in Western Germany the antibiotic has given very poor results.

Control of downy mildew by the use of resistant hop varieties has not reached an advanced stage, except in Western Germany, where two new resistant varieties have been distributed to growers. There is no information regarding physiological specialization in Pseudoperonospora humuli, but there appear to be differences in the susceptibility to downy mildew of certain commercial varieties in different countries, and the possibility of physiological specialization should therefore be borne in mind when breeding for disease resistance.

On the final day, with A. F. Posnette (U.K.) in the chair, there were short discussions on miscellaneous diseases, including powdery mildew (Sphaerotheca humuli), canker (Gibberella pulicaris), Botrytis infection of cones, a heptachlor-induced die-out of hop crowns in Washington State, and Phytophthora rots in New Zealand and Britain.

The conference was supported by the Agricultural Research Council and the Hops Marketing Board.

P. W. Talboys 